Elias Kallas Filho ${ }^{1}$ João Paulo de Oliveira Fonseca ${ }^{1}$

\title{
A INFLUÊNCIA DA PROVA PERICIAL NAS DECISÕES JUDICIAIS ACERCA DA RESPONSABILIDADE CIVIL DOS MÉDICOS
}

The influence of expert testimony on legal decisions regarding the civil liability of doctors

${ }^{1}$ Faculdade de Direito do Sul de Minas. Pouso Alegre/MG, Brasil. Correspondência: Elias Kallas Filho. E-mail: ibnkallas@uol.com.br.

Recebido em: 09/12/2014. Revisado em: 14/05/2015. Aprovado em: 18/05/2015. 


\section{RESUMO}

O presente trabalho tem por objetivo estudar a prova pericial no contexto da resolução das demandas judiciais sobre a responsabilidade civil dos médicos. Para tanto, a pesquisa desdobra-se, inicialmente, sobre um campo teórico, abordando a questão da prova pericial e sua relação com as demais provas admitidas pelo Direito na perspectiva do processo civil pátrio, ressaltando o princípio da persuasão racional do juiz; num segundo momento, a pesquisa recai sobre a análise jurisprudencial do Tribunal de Justiça de Minas Gerais. Com a coadunação entre essas duas dimensões da pesquisa, foi possível constatar um elevado grau de convergência entre as decisões do tribunal mineiro e as conclusões da prova pericial.

\section{Palavras-Chave}

Prova Pericial; Responsabilidade Civil dos Médicos.

\section{ABSTRACT}

The current study seeks to investigate expert's testimony in the context of the resolution of judicial demands on the civil liability of doctors. For this purpose, the research first focuses on relevant theories and raises the question of expert testimony and its relationship to the other evidence permitted under law in civil lawsuits, with an emphasis on the principle of rational persuasion of the judge. Thereafter, the research focuses on the jurisprudential analysis of the Court of Justice of Minas Gerais State in Brazil. By combining these two dimensions of research, the study was able to determine a high degree of convergence between the decisions in the Court of Justice of Minas Gerais and expert testimony conclusions.

\section{Keywords}

Civil Liability of Doctors; Expert Testimony. 


\section{Introdução}

A ordenação processualista civil brasileira adota como princípio basilar o entendimento de que, entre os meios de prova admitidos pelo sistema, não há qualquer gradação prévia. Pelo contrário, a própria lei atribui ao magistrado o dever de, ao julgar o caso concreto, aferir qual das provas trazidas aos autos confirma aquilo que fora alegado, de modo a formar, assim, seu convencimento.

Entretanto, não obstante essa paridade conferida pela lei aos meios de prova, não se pode olvidar de que determinados casos reclamam, para sua melhor solução, o pronunciamento de algum especialista de área das ciências. Pode-se dizer que o próprio Código de Processo Civil $(\mathrm{CPC})^{1}$ reconhece essa possibilidade ao estatuir, em seu artigo $420^{2}$, a perícia como meio de prova. A prova pericial demanda, em decorrência de sua própria natureza de "exame, vistoria ou avaliação", um determinado conhecimento específico.

Esta pesquisa objetiva estudar a influência que a prova pericial assume no caso concreto, especificamente nas demandas que envolvem a responsabilidade civil dos médicos, tendo sempre como parâmetro de análise a suprarreferida paridade que a lei confere aos meios de prova. Afinal, se de um lado há a paridade probatória, de outro há, conforme o caso, a necessidade de um conhecimento técnico específico para se definirem os contornos dos fatos litigiosos.

Para tanto, será empreendido o estudo de casos práticos, dos quais se aferirá a suposta relevância que o julgador confere à prova pericial, a partir dos acórdãos proferidos pelo Tribunal de Justiça do Estado de Minas Gerais (TJMG) publicados no ano de 2013.

Essa problemática existente entre o conjecturado relevo assumido pela prova pericial quando das decisões sobre a responsabilidade civil dos profissionais médicos não se encontra demonstrada em pesquisas científicas, permanecendo, pois, no campo das suposições. Este estudo buscará, portanto, qual a importância da prova pericial no deslinde das controvérsias judiciais relativas à responsabilidade civil dos médicos.

A pesquisa desdobrar-se-á em dois campos: um teórico e outro prático. Para o estudo no campo teórico, empregará o método analítico, debruçando-se sobre a legislação e a doutrina pertinentes ao tema. Para o campo prático, valer-se-á da pesquisa jurisprudencial por meio do sítio eletrônico do TJMG.

\footnotetext{
${ }^{1}$ BRASIL. Lei Federal n. 5.869, de 11 de janeiro de 1973. Institui o Código de Processo Civil. Disponível em: <http://www.planalto.gov.br/ccivil_03/leis/L5869compilada.htm>. Acesso em: 21 ser. 2015.

${ }^{2}$ Idêntica é a redação do artigo 464, caput, da Lei n. 13.105/2015, que institui o novo Código de Processo Civil: "A prova pericial consiste em exame, vistoria ou avaliação". BRASIL. Lei Federal n. 13.105, de 16 de março de 2015. Código de Processo Civil. Disponível em: <http://www.planalto.gov.br/ccivil_03/_Ato20152018/2015/Lei/L13105.htm>. Acesso em: 21 set. 2015.
} 
Por meio do sistema de acórdãos daquele tribunal, serão levantadas todas as decisões que contenham as expressões "erro médico" e "perícia", limitando-se temporalmente a pesquisa àquelas decisões publicadas no ano de $2013^{3}$.

\section{Provas e meios de prova no CPC}

Ao se estudar o papel de uma espécie determinada de prova - qual seja a prova pericial - em relação aos casos concretos que envolvam a responsabilidade civil dos profissionais médicos, parece ser imprescindível uma análise anterior acerca da distinção entre prova e meios de prova, bem como, feito isso, verificar qual o tratamento legal que o estatuto processual civil confere às provas.

Tanto o sujeito que pleiteia em juízo como aquele que resiste à pretensão contra ele formulada necessitam, para que a demanda a ser decidida lhes seja favorável, demonstrar a veracidade das alegações que fazem. E tal demonstração se faz, justamente, por meio das provas que as partes levam aos autos. São essas provas que devem reproduzir, com a maior fidedignidade possível, os fatos que ensejaram a propositura da ação judicial ou, quanto à defesa, que demonstrem a improcedência do pedido do autor.

Assim, numa acepção objetiva, tem-se como conceito de prova justamente a ideia de que ela leva aos autos o conhecimento de um dado fato pertinente à causa. Já numa acepção subjetiva, como trata também a doutrina, prova é a demonstração nos autos que leva o julgador à certeza ou, em suma, é ela que forma no julgador a certeza quanto ao fato que demonstrou ${ }^{4}$.

Vê-se, portanto, que essa dupla acepção acerca do conceito de prova realça dois aspectos que lhe são fundamentais: a prova traz aos autos, ou seja, à realidade do processo, a indicação da ocorrência dos fatos que são caros à demanda, bem como são as grandes responsáveis, num juízo de mérito da causa, pela construção da conviç̧ão do julgador.

Entretanto, é mister destacar que a prova não tem o cunho de repetir identicamente os fatos que se deram. Não se pode querer que a prova reproduza com absoluta exatidão a ocorrência dos fatos, pois tal capacidade lhe escapa. A prova, como já mencionado nas linhas iniciais deste estudo, tem por escopo a demonstração da veracidade das alegações, o que a distingue, por óbvio, da estrita reprodução dos fatos.

\footnotetext{
${ }^{3}$ Para mais detalhes sobre a pesquisa jurisprudencial e o método aplicado, ver item III deste estudo.

${ }^{4}$ THEODORO JÚNIOR, Humberto. Curso de direito processual civil: teoria geral do direito processual civil e o processo de conhecimento. 54. ed. Rio de Janeiro: Forense, 2013. p. 451.
} 
Correta, pois, é a afirmação de que a prova "pretende demonstrar a certeza aproximada" , uma vez que é um instrumento incapaz de reproduzir a realidade em sua inteireza. A prova consegue, ao menos, aproximar-se da dita realidade e, assim, auxiliar o julgador na formação de seu convencimento motivado.

Fixado, então, o entendimento daquilo que se conceitua como prova, passa-se ao estudo dos meios de prova. Os meios são os métodos que as partes (ou o próprio juízo, conforme o caso) podem valer-se para introduzir determinada prova no processo.

O CPC, em seu artigo 332, aceita como meios de prova todos os legais, "bem como os moralmente legítimos", mesmo que não elencados em seu texto. Imperiosa a menção ao artigo $5^{\circ}$, inciso LVI, da Constituição Federal ${ }^{6}$, que trata como "inadmissíveis, no processo, as provas obtidas por meios ilícitos".

A lei instrumental civil especifica, no referido artigo, como meios de prova: depoimento pessoal; confissão; exibição de documento ou coisa; prova documental; prova testemunhal; prova pericial; inspeção judicial. Já a doutrina, de modo a exemplificar um meio de prova que, não obstante ausente do rol do CPC, é tido como moralmente aceito, traz a prova emprestada ${ }^{7}$.

A Lei Federal n. 13.105/2015, que institui o novo Código de Processo Civil, repete, no artigo 369, a sistemática do artigo 332 da vigente lei instrumental civil; e, também quanto aos meios de prova típicos, mantém basicamente a menção daqueles presentes no vigente Código.

Observa-se, portanto, que os meios de prova são aqueles legalmente estatuídos e também aqueles moralmente idôneos.

A perícia, especificamente, é caracterizada pelo artigo 420 do vigente Código como a prova consistente em exame, vistoria ou avaliação. $\mathrm{O}$ primeiro elemento diz respeito à análise de pessoas, animais e bens móveis; o segundo refere-se a bens imóveis; e o último elemento relaciona-se com o cálculo de importâncias monetárias em diferentes níveis ${ }^{8}$.

Assim, sua inserção na relação jurídico-processual dá-se por meio da atuação de um terceiro não interessado, possuidor de conhecimento técnico específico, que produz um laudo imparcial, apto a influir no julgamento da causa, na medida em que contribui para a elucidação de uma questão controversa que demande conhecimentos especiais 9 .

\footnotetext{
${ }^{5}$ MONTENEGRO FILHO, Misael. Curso de direito processual civil. 5. ed. São Paulo: Atlas, 2009. p. 410.

${ }^{6}$ BRASIL. Constituição da República Federativa do Brasil de 1988. Disponível em: <http://www.planalto.gov. br/ccivil_03/constituicao/ConstituicaoCompilado.htm>. Acesso em: 16 set. 2015.

${ }^{7}$ THEODORO JÚNIOR, Humberto. op. cit., p. 467.

${ }^{8}$ MONTEGRO FILHO, Misael. Código de Processo Civil comentado e interpretado. São Paulo: Atlas, 2008. p. 466.

${ }^{9}$ Id. Ibid., p. 466.
} 
Embora caiba tão somente ao juiz a nomeação do perito, conforme se lê no artigo $421^{10}$, caput, da lei instrumental civil, quaisquer das partes na relação jurídico-processual têm legitimidade para requerê-lo. Caso não o façam, poderá também o juiz determinar de ofício a produção da prova pericial, assim como de outras diligências probatórias que entenda úteis para a apuração dos fatos alegados ${ }^{11}$.

Tal possibilidade de o juiz atuar na promoção de diligências probatórias decorre do artigo $130^{12}$ do CPC, segundo o qual “[c]aberá ao juiz, de ofício ou a requerimento da parte, determinar as provas necessárias à instrução do processo, indeferindo as diligências inúteis ou meramente protelatórias".

Esse expediente colocado à disposição do magistrado consubstancia o denominado poder de instrução do juiz ${ }^{13}$. Nesse aspecto, contudo, é importante ressaltar que a atuação do juiz no âmbito de seu poder de instrução não pode ser tal que acabe por lhe solapar a imparcialidade, a qual é substancial para a reta atuação da jurisdição estatal.

Assim, a atuação do juiz no bojo de seu poder de instrução deve voltar-se tão somente à produção das provas que entenda necessárias para a formação de seu livre convencimento, devendo abster-se, em absoluto, de usar tal poder para agir tendenciosamente em relação a qualquer jurisdicionado.

\section{Valoração e a prova pericial}

Feita a distinção entre os conceitos de prova e meios de prova, resta que se faça o necessário estudo de como se procede à valoração da prova no caso concreto.

Entende-se que, na história do processo, três foram os sistemas que vigoraram a respeito da valoração da prova, quais sejam: (a) sistema da prova legal; (b) sistema da valoração secundum conscientiam; e (c) sistema da persuasão racional do juiz ${ }^{14}$.

No primeiro sistema, a própria lei se antecipava aos casos concretos e prefixava o valor probatório de dada prova. Era a lei, portanto, em sua abstração, que trazia em seu bojo a valoração da prova, não se admitindo qualquer manejo, mesmo que moderado, do julgador ante ao conjunto probatório ${ }^{15}$.

\footnotetext{
${ }^{10} \mathrm{O}$ dispositivo correspondente na Lei Federal n. 13.105/2015 é o artigo 465, caput: “O juiz nomeará perito especializado no objeto da perícia e fixará de imediato o prazo para a entrega do laudo".

${ }^{11}$ BARRETO, Ricardo de Oliveira Paes. Curso de direito processual civil. 3. ed. rev. e atual. Rio de Janeiro: Renovar, 2006. p. 416.

${ }^{12}$ Cujo correspondente na Lei Federal n. 13.105/2015 é o artigo 370, caput: "Caberá ao juiz, de ofício ou a requerimento da parte, determinar as provas necessárias ao julgamento do mérito".

${ }^{13}$ THEODORO JÚNIOR, Humberto. op. cit., p. 457.

${ }^{14}$ CINTRA, Antônio Carlos de Araújo; GRINOVER, Ada Pellegrini; DINAMARCO, Candido Rangel. Teoria geral do processo. 27. ed. São Paulo: Malheiros Ed., 2011. p. 381.

${ }^{15}$ MONTENEGRO FILHO, Misael. Curso de direito processual civil, cit., p. 431.
} 
Diametralmente oposto ao primeiro, o segundo sistema preconizava maior liberdade do magistrado na valoração das provas. O julgador dirimia a controvérsia analisando o conjunto probatório da maneira que lhe aprouvesse, podendo, inclusive, dispensar as provas e decidir o caso conforme suas próprias convicções, sequer havendo a necessidade de fundamentação para tanto ${ }^{16}$.

Por derradeiro, no sistema da persuasão racional o juiz, embora não completamente desvinculado do conjunto probatório (como quer o sistema da valoração secundum conscientiam), não está sujeito às amarras da lei que prefixa a valoração das provas (como quer, ao seu turno, o sistema da prova legal) ${ }^{17}$. Vê-se, nesse sistema, que não é lícito ao magistrado decidir como lhe aprouver e que ele tampouco fica obrigado a decidir em conformidade com uma valoração que a lei anteriormente tenha fixado.

O juiz, portanto, tem amplas possibilidades de analisar todo o conjunto probatório constante dos autos (considerando, até mesmo, questões relevantes relativas às provas, como a incumbência de seu ônus) e, embora a lei não valore as provas previamente, cabe ao julgador o dever da fundamentação. Conclui-se que o sistema da persuasão racional erige-se sobre os seguintes fundamentos: se há a liberdade na formação do convencimento do julgador pela análise das provas, também há, em um mesmo grau, a obrigação da fundamentação, em outras palavras, obrigação de exteriorização do raciocínio que levou o juiz a decidir.

O direito pátrio perfilha, assim, este último sistema, tal como se depreende da leitura do artigo $131^{18}$ do CPC, que estatui que o magistrado "apreciará livremente a prova" e, conseguintemente, indicará "os motivos que lhe formaram o convencimento". Notam-se claramente nesse dispositivo da lei instrumental civil os dois baluartes do sistema da persuasão racional mencionados.

Ainda quanto à premente necessidade de fundamentação da decisão do julgador, é imprescindível ressaltar o texto do artigo 93, inciso IX, da Constituição Federal ${ }^{19}$, que colima a pena de nulidade para a decisão judicial carecedora de fundamentos.

Em suma: claro está que, ante o vigente ordenamento jurídico pátrio, no que concerne à valoração atribuída às provas, a lei abstém-se de determinar previamente

\footnotetext{
${ }^{16}$ MONTENEGRO FILHO, Misael. Curso de direito processual civil, cit., p. 431.

${ }^{17}$ CINTRA, Antônio Carlos de Araújo; GRINOVER, Ada Pellegrini; DINAMARCO, Candido Rangel. op. cit., p. 74.

${ }^{18}$ Corresponde ao artigo 371 da Lei Federal n. 13.105/2015: “O juiz apreciará a prova constante dos autos, independentemente do sujeito que a tiver promovido, e indicará na decisão as razões da formação de seu convencimento".

19 “Art. 93. [...] IX - todos os julgamentos dos órgãos do Poder Judiciário serão públicos, e fundamentadas todas as decisões, sob pena de nulidade, podendo a lei limitar a presença, em determinados atos, às próprias partes e a seus advogados, ou somente a estes, em casos nos quais a preservação do direito à intimidade do interessado no sigilo não prejudique o interesse público à informação; (Redação dada pela Emenda Constitucional $n^{\circ} 45$, de 2004)".
} 
seu valor probatório. Esse ofício recai sobre o juiz, que deve apreciá-las livremente de modo a formar seu convencimento, alicerçando-o com maior razão na melhor demonstração da realidade que determinada(s) prova(s) conseguiu(ram) trazer aos autos.

Contudo, mesmo estando comprovada a vigência do princípio do livre convencimento motivado, pode-se dizer, ainda, que há casos em que o ordenamento jurídico adota o modelo da prova legal (que corresponde ao primeiro dos sistemas citados). Seria a hipótese do artigo $366^{20}$ do CPC, segundo o qual "[q]uando a lei exigir, como da substância do ato, o instrumento público, nenhuma outra prova, por mais especial que seja, pode suprir-lhe a falta".

Nesse caso, teria a lei procedido com a tarifação da prova, mitigando, de certo modo, o princípio do livre convencimento motivado. Assim, há o entendimento de que "[a] inexistência de hierarquia entre os meios de prova sempre desaparecerá quando houver norma expressa determinando a prevalência de um meio sobre o outro"21.

Resta clara, portanto, a primazia do princípio do livre convencimento motivado, não se excluindo, contudo, casos que em que a lei expressamente opte pela prova legal, como, v. g., na hipótese acima mencionada do artigo 366 do CPC.

Pertinente que se investigue se a perícia, meio de prova que é, encontra-se sob a égide do princípio da persuasão racional ou se constitui exceção desse princípio, preponderando sobre as demais provas, mormente no que diz respeito às decisões judiciais acerca da responsabilidade civil dos médicos.

Mister, portanto, o estudo sobre o artigo $436^{22}$ do CPC, o qual estatui, in verbis: "o juiz não está adstrito ao laudo pericial, podendo formar a sua convicção com outros elementos ou fatos provados nos autos".

Ora, se, como dito anteriormente, apenas a expressa menção legal pode excepcionar a vigência do princípio da persuasão racional do juiz - este, pois, tido como regra no processo civil pátrio -, as letras do artigo 436 do CPC tão somente reforçam ao julgador o vigor desse princípio em relação à prova pericial. $\mathrm{O}$ laudo pericial, portanto, não faz prova absoluta e não prevalece em relação às demais que estejam presentes nos autos.

Atribui-se a redação do artigo 436 do CPC à cautela do legislador, que, ante à possibilidade de o julgador ver-se diante de uma causa que demande conhecimento

\footnotetext{
${ }^{20} \mathrm{Na}$ mesma ordem de ideias o artigo 406 da Lei Federal n. 13.105/2015: "Quando a lei exigir instrumento público como da substância do ato, nenhuma outra prova, por mais especial que seja, pode suprir-lhe a falta". ${ }^{21}$ WAMBIER, Luiz Rodrigues; TALAMINI, Eduardo. Almeida, Flávio Renato Correia de (Coords.). Curso avançado de processo civil: teoria geral do processo e processo de conhecimento. 10. ed. rev. atual., e ampl. São Paulo: Ed. Revista dos Tribunais, 2008. p. 451.

${ }^{22} \mathrm{Em}$ seu artigo 479, a Lei Federal n. 13.105/2015 conserva a não adstrição do juiz ao laudo pericial: "O juiz apreciará a prova pericial de acordo com o disposto no art. 371 , indicando na sentença os motivos que o levaram a considerar ou a deixar de considerar as conclusões do laudo, levando em conta o método utilizado pelo perito".
} 
técnico específico que lhe fuja do saber, preferiu, por bem, ressaltar a primazia do princípio da persuasão racional. Assim, a cautela do legislador "mostra-se útil no sentido de evitar qualquer tentação a um tratamento excepcional, motivado pela premissa da falta de conhecimento em princípio do juiz sobre o tema [...]"23.

Não pode ser outra a conclusão senão a de que a prova pericial, ante o ordenamento jurídico vigente e o princípio da persuasão racional que lhe norteia, não é dotada de qualquer tarifação legal que a privilegie no caso concreto. Caberá, pois, ao juízo do juiz ${ }^{24}$ decidir sobre o caso concreto, se eventual prova pericial - conjuntamente ou não com outras - demonstrar maior certeza em relação aos fatos pertinentes à causa do que todo o restante do conjunto probatório.

Essa situação, como não poderia deixar de ser, aplica-se também às demandas judiciais sobre a responsabilidade civil dos médicos. É evidente que tais casos, não raramente, reclamam um pronunciamento técnico, uma vez que a ciência médica em si comporta um sem número de especializações, tendo em função disso, mesmo em seu bojo, especialistas em suas diversas áreas. Assim, não se pode querer um pronunciamento peremptório do magistrado acerca de algum elemento médico quando tal elemento for do conhecimento apenas de certos especialistas dessa ciência.

Entretanto, essa manifesta necessidade de conhecimento médico específico para a solução do caso concreto não pode significar uma primazia da prova pericial. E assim o é porque, reitera-se, o ordenamento jurídico elegeu como orientador, no que concerne à valoração das provas, o princípio da persuasão racional.

Contudo, também dizer que a lei, em regra, não realiza uma valoração prévia das provas, deixando esse encargo ao julgador, não pode denotar que, ao solucionar do caso, o juiz não possa ter como baluarte de sua decisão a prova pericial. Se assim proceder, é porque essa prova formou sua convicção, em função de sua verossimilhança com os fatos pertinentes à causa.

Urge, desse modo, uma vez expostas essas diretrizes legais e doutrinárias acerca da prova e sua valoração, que se analise como se comporta a jurisprudência ante a prova pericial no contexto das decisões sobre a responsabilidade civil dos médicos: assume a perícia algum relevo notável, mormente em função da supracitada especialidade da ciência médica?

\section{Responsabilidade do médico e a perícia na jurisprudênca do TJ/MG}

Fixados os contornos teóricos e legais a respeito da prova pericial, tanto no contexto geral do processo civil como naquele específico referente à responsabilidade

\footnotetext{
${ }^{23}$ MARCATO, Antônio Carlos et al. (Coords.). Código de Processo Civil interpretado. São Paulo: Atlas, 2004. p. 1337.

${ }^{24}$ CARNELUTTI, Francesco. Como se faz um processo. Belo Horizonte: Líder, 2008. p. 47.
} 
civil do médico, passe-se ao estudo prático. Assim, analisar-se-á o comportamento da jurisprudência no enfrentamento de tais causas sob o aspecto do relevo que pode a perícia assumir na fundamentação da decisão judicial.

No que concerne ao campo prático da pesquisa, portanto, a coleta de jurisprudência teve vez no site do TJMG (www.tjmg.jus.br), seguindo o caminho "Jurisprudência" > "Consulta de Jurisprudência" > "Acórdãos" > "Sistema de Acórdãos". A consulta foi efetuada com o emprego das expressões "erro médico" e "perícia".

De modo a limitar o período correspondente à publicação dos acórdãos, bem como objetivando zelar pela atualidade de tais dados jurisprudenciais, fixou-se como interregno as datas de $1^{\circ}$ de janeiro de 2013 a 31 de dezembro de 2013. A consulta para a coleta dessas decisões deu-se em 18 de abril de 2014, às $10 \mathrm{~h} 57$.

Esta feita, colecionou-se o total de 30 acórdãos, os quais foram organizados em uma tabela eletrônica, de modo a facilitar o acesso, a compreensão e o estudo dos dados. A tabela foi estruturada conforme os seguintes itens: número do acórdão; data de publicação; menção a outras provas; menção à perícia; decisão em conformidade com a perícia; manutenção da sentença; justiça gratuita ${ }^{25}$.

Dentre as decisões obtidas, por não guardarem qualquer pertinência com o estudo desenvolvido, foram excluídos nove acórdãos referentes a embargos infringentes, agravos de instrumento, agravo interno e apelações criminais, bem como três apelações civis ${ }^{26}$.

É, portanto, dos 21 acórdãos remanescentes - os quais têm origem apenas em apelações civis - que se aferirá, ante os casos concretos, o lastro probatório conferido à prova pericial para a solução das controvérsias que recaem sobre a responsabilidade civil dos médicos ${ }^{27}$.

O primeiro resultado relevante extraído da pesquisa demonstra que, das decisões restantes, apenas duas divergiram da prova técnica produzida pelo perito do juízo, o que representa $9,52 \%{ }^{28}$ entre o universo das 21 decisões. Isto é, as decisões, em $90,48 \%$ dos julgados estudados, perfilharam-se às conclusões da prova técnica.

\footnotetext{
${ }^{25}$ Ver Anexo I. Relação analítica de acórdãos.

${ }^{26}$ Entre essas três decisões, uma trata da responsabilidade do Estado por erro judiciário; outra, da responsabilidade por abalo em estrutura de imóvel e perturbações sonoras em decorrência do funcionamento de linha férrea; e a terceira fora excluída por fundamentar-se em laudo do IML, o qual não constitui prova pericial.

${ }^{27}$ São as apelações cíveis de números 1.0027.06.093489-3/001, 1.0194.09.097459-4/001, 1.0134.09.111745-4/001, 1.0145.09.547060-8/001, 1.0024.07.775472-9/001, 1.0396.03.006913-4/001, 1.0521.03.028416-5/001, 1.0620.10.002878-1/001, 1.0024.09.450824-9/003, 1.0027.06.106008-6/001, 1.0417.05.003914-4/001, 1.0223.05.181694-8/005, 1.0145.10.021493-4/001, 1.0024.03.026384-2/001, $1.0035 .06 .074653-0 / 001, \quad 1.0261 .04 .029803-4 / 003, \quad 1.0525 .08 .149285-8 / 001, \quad 1.0145 .07 .425986-$ 5/001, 1.0024.05.708630-8/001, 1.0024.08.219726-0/005, 1.0105.08.254921-0/001.

${ }^{28}$ Por critérios de aproximação numérica, utilizar-se-á, no máximo, para a apresentação de dados nesta pesquisa, duas casas decimais.
} 
É de se notar, contudo, que essas duas decisões não se perfilharam à prova pericial em função de considerá-la conspurcada por algum vício. Em uma delas (n. 1.0194.09.097459-4/001), o julgador considerou a prova técnica "de baixa qualidade, com respostas absolutamente lacunosas e que, de forma alguma, serve à elucidação do caso, sem falar na especialidade de conteúdo diverso daquele buscado". Assim sendo, decidiu-se pela realização de nova perícia, anulando-se parcialmente o feito.

Já em relação ao segundo decisório (n. 1.0024.09.450824-9/003), não se decidiu em consonância com a perícia porque o tribunal entendeu pela necessidade de nova intimação do perito para prestar esclarecimentos, anulando-se a sentença, uma vez que tal prova não atendeu a anterior decisão do tribunal que determinara os tais esclarecimentos.

Esses fatos são em demasia relevantes, pois se depreende que essas decisões divergiram da prova pericial não porque todo o restante do conjunto probatório estava a demonstrar a ocorrência de outros fatos, mas porque a perícia apresentava alguma mácula. Talvez em função de a perícia vislumbrar a exposição de "fatos complexos" 29 - e o erro médico certamente se enquadra nestes termos - é que o tribunal, nessas duas decisões, preferiu sanar os vícios que o inquinavam a ter de decidir em seu detrimento.

Tem-se também como outro dado relevante a ser extraído da pesquisa o fato de que, tendo por fundamento a prova pericial - ressalvando-se, portanto, os dois casos supracitados -, ela foi o sustentáculo das decisões quer para a manutenção das sentenças, o que se deu em 16 acórdãos $(84,2 \%)$, quer para sua reforma, o que ocorreu em três acórdãos (15,8\%).

Em relação às três decisões que reformaram o decisório de primeiro grau, duas decidiram por afastar o dever de indenizar; enquanto a outra decidiu pela indenização, mas sempre com supedâneo na prova pericial.

Em um desses acórdãos (n. 1.0521.03.028416-5/001), “[a] perícia técnica realizada em juízo concluiu pela ausência de erro médico no procedimento realizado [...]", o que acarretou a consequente reforma da sentença "[...] ante a ausência de ato ilícito, o que afasta o dever de indenizar". Em outro (n. 1.0105.08.254921-0/001), também se reformou a decisão de primeiro grau, posto que por maioria. A perícia demonstrou "que não houve erro de procedimento, tendo a anestesia sido ministrada corretamente [...]", decidindo-se por afastar o dever de indenizar dos réus.

Já no terceiro caso (n. 1.0620.10.002878-1/001), a perícia elaborada demonstrou "[...] configurada(s) a imperícia e a negligência do Réu [...]", desta forma reformou-se a sentença e deu-se provimento à pretensão indenizatória.

\footnotetext{
${ }^{29}$ Apelação Cível no 1.0024.09.450824-9/003.
} 
É sempre importante advertir que a jurisprudência desse tribunal não deixa, dados os motivos já expostos neste trabalho, de reconhecer a vigência do sistema da persuasão racional do juiz no processo civil pátrio. É o que se realça, por exemplo, pelo excerto do seguinte julgado (n. 1.0024.05.708630-8/001):

É certo que o convencimento do juiz fica condicionado aos fatos
sobre os quais se funda a controvérsia (quod non est in actis non
est in mundo), as regras legais e as máximas de experiência. Con-
vicção livre, mas motivada ou fundamentada, consoante a prova
produzida no processo.

De outro giro, parece ser evidente a constatação de que a perícia é fundamental para as decisões judiciais acerca da responsabilidade civil dos médicos no bojo da jurisdição do tribunal mineiro. Não se descuida de todo o restante do conjunto probatório ${ }^{30}$, mas certamente, em função da maior especialidade dessa espécie de prova, os julgadores tendem a tê-la com maior zelo, pois ela "visa a suprir os conhecimentos técnicos que o magistrado não possui" ${ }^{31}$. Elucidam essas palavras os dizeres do desembargador Eduardo Mariné da Cunha de que "[e]sta Corte tem entendido que o Julgador deve-se pautar pelas conclusões do perito, quando o deslinde do feito depender de conhecimento técnico que apenas este detém: [...]."32

O que se consegue extrair de tais palavras, inclusive pelo que é destacado no teor desse acórdão - até mesmo pela ressalva feita à dicção os artigos 436 e 437 da lei instrumental civil -, é que, se todo o restante do conjunto probatório não sobrepujar aquilo que a perícia logrou em demonstrar, esta tenderá a prevalecer na formação do convencimento do julgador.

Foi o que se argumentou literalmente: “[...] o julgador apenas poderá deixar de basear sua decisão nas conclusões do perito, caso as demais provas presentes nos autos indiquem, com segurança, que os fatos não ocorreram conforme descritos pelo experto"33.

Por fim, é importante ressaltar que, no curso desta pesquisa, destacaram-se dados concernentes à concessão do benefício da justiça gratuita aos autores das demandas. Muito embora essa questão não integre o objeto específico da presente pesquisa, trata-se de achado que se reputou importante mencionar, uma vez que poderá motivar novas investigações sobre a matéria. Dentre os 21 casos que compõem esta pesquisa, em sete deles não foi possível confirmar nem descartar a concessão do benefício da justiça gratuita, pelo fato de que, no relatório do acórdão,

\footnotetext{
${ }^{30}$ Como na Apelação Civil n. 1.0105.08.254921-0/001, em que a prova testemunhal corroborara com aquilo que demonstrou a perícia.

${ }^{31}$ Apelação Cível n. 1.0525.08.149285-8/001

${ }^{32}$ Apelação Cível n. 1.0134.09.111745-4/001.

${ }^{33}$ Apelação Cível n. 1.0134.09.111745-4/001.
} 
não se fez menção à concessão desse benefício em primeiro grau de jurisdição e, em consulta ao andamento processual no endereço eletrônico do tribunal mineiro, tampouco se obtiveram tais informações. Assim, dada a segurança quanto aos dados, ressalvam-se tais decisões.

Advertência feita, constata-se que, em $85,7 \%$ das decisões remanescentes, o autor da demanda encontra-se sob o pálio da justiça gratuita. É forçosa a conclusão de que, ao menos nas causas relativas à responsabilidade civil dos médicos, a concessão da justiça gratuita aos autores das demandas é francamente preponderante.

É interessante notar, especificamente quanto à natureza das causas aqui tratadas, que a Lei Federal n. 1.060/1950, no inciso V de seu artigo $3^{\circ}$, estatui que a isenção recairá sobre os honorários de advogados e peritos. Isso significa que, eventualmente, se o autor da demanda tiver seus pedidos tidos como improcedentes, estará desobrigado em relação às verbas sucumbenciais, nos termos da legislação ${ }^{34}$. Nesse sentido, a alta porcentagem de concessão do benefício pode até mesmo suscitar a discussão sobre se tratar de um instrumento catalisador das demandas judiciais dessa natureza, o que, todavia, como já salientado, extrapola o âmbito da presente investigação.

\section{Considerações finais}

A análise dos resultados obtidos demonstra que, no TJMG, a prova pericial é dotada de especial relevo pelo julgador para o deslinde das demandas judiciais que envolvem a responsabilidade civil dos profissionais médicos. E esse relevo ficou evidenciado pelo alto grau de convergência entre as decisões do tribunal em relação às demonstrações da prova técnica.

Tal constatação não significa dizer que o TJMG descuida do conjunto probatório em sua inteireza. Entretanto, evidencia que, por se tratar a responsabilidade civil dos médicos de uma questão em que se tem como imprescindível a elucidação de inúmeros pormenores de natureza eminentemente técnica, não se pode olvidar de que a prova pericial, dada sua própria natureza, é a que melhor coaduna para tais fins.

Destarte, à luz dos invocados fundamentos teóricos e legais, bem como das decisões analisadas, vê-se que apenas um conjunto probatório robusto ou determinado vício que inquine a prova pericial, ilidindo a demonstração especializada dos

\footnotetext{
${ }^{34}$ Têm destaque os seguintes artigos da Lei Federal n. 1.060/1950: "Art. 12. A parte beneficiada pela isenção do pagamento das custas ficará obrigada a pagá-las, desde que possa fazê-lo, sem prejuízo do sustento próprio ou da família, se dentro de cinco anos, a contar da sentença final, o assistido não puder satisfazer tal pagamento, a obrigação ficará prescrita". "Art. 13. Se o assistido puder atender, em parte, as despesas do processo, o Juiz mandará pagar as custas que serão rateadas entre os que tiverem direito ao seu recebimento". BRASIL. Lei Federal n. 1.060, de 5 de fevereiro de 1950. Estabelece normas para a concessão de assistência judiciária aos necessitados. Disponível em: <http://www.planalto.gov.br/ccivil_03/ LEIS/L1060compilada.htm>. Acesso em: 21 set. 2015.
} 
fatos que dela se espera, poderão, no contexto das demandas desta natureza, ensejar uma decisão judicial que divirja do laudo pericial. E esse fenômeno explica-se por aquilo que fora escrito antes: trata-se da melhor correspondência que um meio de prova tem em relação àquilo que se quer comprovar.

\section{Referências}

BARRETO, Ricardo de Oliveira Paes. Curso de direito processual civil. 3. ed. rev. e atual. Rio de Janeiro: Renovar, 2006.

CARNELUTTI, Francesco. Como se faz um processo. Belo Horizonte: Líder, 2008.

CINTRA, Antônio Carlos de Araújo; GRINOVER, Ada Pellegrini; DINAMARCO, Candido Rangel. Teoria geral do processo. 27. ed. São Paulo: Malheiros Ed., 2011.

KFOURI NETO, Miguel. Responsabilidade civil do médico. 5. ed. rev. e atual. São Paulo: Ed. Revista dos Tribunais, 2003.

MARCATO, Antônio Carlos et al. (Coords.). Código de Processo Civil interpretado. São Paulo: Atlas, 2004.

MONTEGRO FILHO, Misael. Código de Processo Civil comentado e interpretado. São Paulo: Atlas, 2008.

Curso de direito processual civil. 5. ed. São Paulo: Atlas, 2009.

THEODORO JÚNIOR, Humberto. Curso de direito processual civil: teoria geral do direito processual civil e o processo de conhecimento. 54. ed. Rio de Janeiro: Forense, 2013.

WAMBIER, Luiz Rodrigues; TALAMINI, Eduardo. Almeida, Flávio Renato Correia de (Coords.). Curso avançado de processo civil: teoria geral do processo e processo de conhecimento. 10. ed. rev. atual., e ampl. São Paulo: Ed. Revista dos Tribunais, 2008.

Elias Kallas Filho - Pós-Doutor da Fundação São Francisco de Assis (Belo Horizonte/MG); doutor em Direito Comercial pela Universidade de São Paulo; graduado em Direito pela Universidade de São Paulo. Professor e coordenador científico e de Pós-Graduação da Faculdade de Direito do Sul de Minas. Advogado. Pouso Alegre/MG, Brasil. E-mail: ibnkallas@uol.com.br.

João Paulo de Oliveira Fonseca - Graduando em Direito pela Faculdade de Direito do Sul de Minas. Pouso Alegre/MG, Brasil. 
Prova pericial nas decisões judiciais sobre responsabilidade civil dos médicos

Anexo I. Relação analítica de acórdãos.

\begin{tabular}{|c|c|c|c|c|c|c|}
\hline Número do acórdão & $\begin{array}{c}\text { Data da } \\
\text { publicação }\end{array}$ & $\begin{array}{c}\text { Menção } \\
\text { a outras } \\
\text { provas }\end{array}$ & $\begin{array}{l}\text { Menção } \\
\text { à perícia }\end{array}$ & $\begin{array}{c}\text { Decisão em } \\
\text { conformidade } \\
\text { com a perícia }\end{array}$ & $\begin{array}{l}\text { Manutenção } \\
\text { da sentença }\end{array}$ & $\begin{array}{l}\text { Justiça } \\
\text { gratuita }\end{array}$ \\
\hline 1.0024.03.0263842/001 & $26 / 04 / 13$ & Sim & Sim & Sim & Sim & $\mathrm{N} / \mathrm{D}$ \\
\hline 1.0024.05.7086308/001 & $22 / 02 / 13$ & Não & Sim & Sim & Sim & Sim \\
\hline 1.0024.07.7754729/001 & $04 / 10 / 13$ & Não & Sim & Sim & Sim & $\mathrm{N} / \mathrm{D}$ \\
\hline 1.0024.08.2197260/005 & $22 / 02 / 13$ & Sim & Sim & Sim & Sim & Sim \\
\hline $1.0024 .09 .4508249 / 003$ & $20 / 06 / 13$ & Sim & Sim & Não & Não ${ }^{1}$ & Não \\
\hline 1.0027.06.0934893/001 & $09 / 12 / 13$ & Sim & Sim & Sim & Sim & $\operatorname{Sim}$ \\
\hline 1.0027.06.1060086/001 & $07 / 06 / 13$ & Não & Sim & Sim & Sim & N/D \\
\hline 1.0035.06.0746530/001 & $26 / 04 / 13$ & Sim & Sim & Sim & Sim & Sim \\
\hline 1.0105.08.2549210/001 & $01 / 02 / 13$ & Sim & Sim & Sim & Não & N/D \\
\hline 1.0134.09.1117454/001 & $03 / 12 / 13$ & Sim & Sim & Sim & Sim & Sim \\
\hline 1.0145.07.4259865/001 & $07 / 03 / 13$ & Sim & Sim & Sim & Sim & Sim \\
\hline 1.0145.09.5470608/001 & $03 / 12 / 13$ & Sim & Sim & Sim & Sim & Sim \\
\hline 1.0145.10.0214934/001 & $26 / 04 / 13$ & Sim & Sim & Sim & Sim & Sim \\
\hline 1.0194.09.0974594/001 & $06 / 12 / 13$ & Não & Sim & Não & Não ${ }^{1}$ & Sim \\
\hline 1.0223.05.1816948/005 & $17 / 05 / 13$ & Sim & Sim & Sim & Sim & Não \\
\hline 1.0261.04.0298034/003 & $01 / 04 / 13$ & Sim & Sim & Sim & Sim & $\mathrm{N} / \mathrm{D}$ \\
\hline 1.0396.03.0069134/001 & $04 / 10 / 13$ & Sim & Sim & Sim & Sim & Sim \\
\hline 1.0417.05.0039144/001 & $28 / 05 / 13$ & Não & Sim & Sim & Sim & Sim \\
\hline 1.0521.03.0284165/001 & $20 / 08 / 13$ & Sim & Sim & Sim & Não & N/D \\
\hline 1.0525.08.1492858/001 & 08/03/13 & Não & Sim & Sim & Sim & Sim \\
\hline 1.0620.10.0028781/001 & $19 / 07 / 13$ & Não & Sim & Sim & Não & $\mathrm{N} / \mathrm{D}$ \\
\hline
\end{tabular}

${ }^{1}$ Sentença anulada, com retorno dos autos à primeira instância para novo julgamento. 